\title{
Alterations in the clinical, hematological and biochemical pictures in abomasal displacement in cows in Egypt
}

\author{
H. M. El-Attar, Yassein M. Abd El-Raof, and M. M. Ghanem \\ Department of Animal Medicine, Faculty of Veterinary Medicine, Benha University \\ Moshtohor, Toukh, Egypt P.O box 13736
}

\begin{abstract}
This study was carried out on twelve Holstein dairy cows. Five cows were clinically healthy and considered as control; three cows with left displacement of abomasum (LDA) and four cows with right displacement of abomasum (LDA). Diagnosis of DA based on clinical examinations and confirmed by ultrasonography. The $\mathrm{Hb}, \mathrm{PCV} \%$, total leucocytic count, neutrophils and abomasal fluid pH were significantly increased $(\mathbf{P}<0.05)$ in $R D A$ compared to control. Serum biochemical analysis showed significant reductions of sodium, potassium, chloride and calcium in LDA and RDA and significant increases $(P<0.05)$ in glucose and total proteins in RDA compared to the control. Moreover, there were significant increases $(P<0.001)$ in ALT, AST, LDH, CPK, urea and creatinine in LDA and RDA compared to control. In conclusion, abomasal displacement produces alterations in the clinical, hematological and biochemical picture compared to control healthy cow and these alterations may vary according to the type of displacement.
\end{abstract}

Abomasal diseases of dairy cattle are mostly associated with stress conditions, nutritional disorders and metabolic disturbances. These diseases include LDA, RDA, abomasal volvulus (AV), abomasal ulcer and abomasal impaction (Schuch, 1993). Abomasal displacement is one of the several conditions that cause post-calving digestive upset and may lead to perplexity in diagnosis of digestive and metabolic diseases in cattle (Constable et al., 1992 b).

Abomasal displacement in cattle is a worldwide disease. It is seen most commonly with higher frequency in regions with intensive cattle breeding and husbandry (Jubb et al., 1991; Pehrson and Shaver, 1992). The disease has a high economic importance in Egyptian industry. After non-surgical correction of the displaced abomasum, the production can be disappointing as it may result in culling of the cow. The total estimated economic loss of a case of DA is between US $\$ 250$ to $\$ 450$ (Bartlett et al., 1995). Geishauser et al. (2000) have calculated the annual loss in North America due to DA as up to 220 million dollar.

A number of factors have been implicated in the etiology of abomasal displacement. The primary causative factor in abomasal displaycement appears to be atony or hypotony of the abomasum (Breukink and de Ruyter, 1976). Dairy cattle with high milk production and being fed large quantities of grain, where exercise is limited may have abomasal atony. Other contributing factors decreasing abomasal motility include metabolic disorders (hypocalcemia and ketosis), concurrent diseases (such as mastitis and metritis), changes of intraabdominal organs (especially in late pregnancy) and genetic predisposition (Rober-tson, 1968; Delgado-Lecaroz et al., 2000; Radostits et al., 2000). Sudden change in the feed before calving, in preparation for lactation promotes abomasal displacement and induces improper adjustment of flora and fauna (Dirsken et al., 1962).

A sudden onset of ruminal stasis, lack of appetite and fall in milk yield may be observed in abomasal displacement and could be also characteristic of acute intestinal obstruction (Sack, 1968). However, in abomasal displacement, the accumulation of gas in the abomasum results in a tympanic, resonant, hightoned ping (Breukink and Kroneman, 1963). The LDA occurs more frequently than RDA in cows and ketosis is frequently seen concurrently with LDA than RDA (Constable et al., 1992 a).

LDA is characterized by partial or complete displacement of the dilated abomasum between the rumen and left abdominal wall (Dirksen, 1962). A high incidence usually occurs in the period from 3-6 weeks after calving (Constable et al., 1991). In addition, there is a high incidence of LDA in winter due to higher frequency of calving and inactivity (Martin, 1972).

It is possible that the clinical LDA resolves spontaneously without medical or surgical interference and these cases are called floaters 
(Van Winden et al., 2003). However, in this paper, there were persistence cases of LDA and RDA that required veterinary intervention.

Therefore, this study aimed at determination of clinical, hematological and biochemical changes as well as the abomasal fluid $\mathrm{pH}$ changes in cows suffering from signs of abomasal displacement after confirmation of the diagnosis by Ultrasonographic examination.

\section{Materials and methods}

Animals. A total number of twelve Holstein dairy cows from a private farm at El-Khatatba, Egypt were used in the present study. The examined animals were allocated into 3 groups. Group I included 5 clinically healthy cows and considered as control. Group II included 3 cows with clinical findings of left abomasal displacement that was confirmed by ultrasonography. Group III included 4 cows with clinical findings of right abomasal displacement.

Clinical examination. Clinical examinations included inspection and recording of respiratory and pulse rates and body temperature. In addition, percussion and auscultation at the left or right rib cage were conducted (Kelly, 1984).

Collection of abomasal fluid for $\mathbf{p H}$ determination. Paracentesis of the displaced abomasum as well as the normal abomasum was carried out using a 16-gague needle to determine the $\mathrm{pH}$ of the aspirated fluid (Schuch, 1993).

Urinalysis. Urine samples from all examined cows were collected for qualitative determination of $\mathrm{pH}$, protein, glucose, ketone bodies, bilirubin and detection of blood and hemoglobin by comber test strips supplied by Boehringer Mannheim, Germany.

Hemato-biochemical Analysis. Two blood samples were collected from jugular vein of examined animals. The first sample was heparinized blood for determination of RBCs count, $\mathrm{Hb}$ concentration, $\mathrm{PCV} \%$ and WBCs count according to Sastry (1985). The second blood sample was collected without anticoagulant, left to clot and non-hemolysed serum was obtained. Commercially available diagnostic kits were used for colorimetric determination of serum calcium (Glinder and King, 1972), sodium and potassium (Henry et al., 1974), chloride (Feldkemp, 1979), glucose (Lott, 1975), total proteins (Doumas et al., 1981), urea (Faweet and Scott, 1960), creatinine (Young, 1990), AST and ALT (Reitman and Frankel, 1957), LDH (Tietz, 1986) and CPK (Rec, 1977).
Ultrasonographic examination of abomasum. Sonoghraphic examination was performed by using a $3.5 \mathrm{MHz}$ linear transducer as previously described (Braun et al., 1997).

Statistical analysis. All results were described as means \pm standard error (SE). All pairwise multiple comparisons of mean values of cattle with LDA, RDA and control were analyzed using one-way analysis of variance (ANOVA) followed by Holm-Sidak method as post hoc test using SigmaStat software (version 3.1, SPSS, Chicago, IL, USA) according to (Gelfert et al., 2006). Values were significantly different from control at $\mathrm{P}<0.05$ or $\mathrm{P}<0.001$.

\section{Results}

Clinical picture. Cases with LDA were diagnosed 21 day post parturient while cases with RDA were diagnosed on the $25^{\text {th }}$ day post parturient (Table 1). The rectal temperature was o significantly affected by the AD $(\mathrm{P}=0.529)$ but the Diseased the respiratory and pulse rates were significantly increase in RDA only ( $p=0.001$, 0.025 , respectively). Ruminal movement was reduced where it was $2 / 2 \mathrm{~min}$ in LDA and $1 / 2 \mathrm{~min}$ in RDA compared to control (3/2min) (Table 2). Clinical examination of diseased cows indicated dullness, poor appetite, sudden drop of milk yield, ketotic breath, scanty pasty faeces, reduction of rumination and distention of the left or right side of the abdomen according the type of displacement. Moreover, high pitched resonant pings were audible on simultaneous percussion and auscultation of the dorsal flank, especially in the cranial third of the paralumbar fossa in cases with LDA. While in the right abomasal displacement, this diagnostic ping sound was heard on the right dorsolateral aspect of the body. On rectal palpation, the rumen was displaced medial than normal in left abomasal displacement, while in right displacement, the distended abomasum was palpated rectally. The displacement of abomasum was confirmed by ultrasonographic examination. The abomasal wall appeared as a narrow echogenic line following the abdominal wall and muscles.

Parts of abomasal folds were visible as elongated, echogenic sickle-shaped structures.

Slow movement of feed within the abomasum was also visualized. In LDA, the abomasum was visualized between the left abdominal wall and the rumen.In other cases of LDA, the abomasal gas cap was not visible because of the reverberation artifacts at the abomasal surface. In RDA, the liver was displaced medially from the right abdominal wall. 
Table (1): Number of cows, mean age and mean post parturient period (in days) in the control, LDA and RDA groups.

\begin{tabular}{lccc}
\hline & \multicolumn{3}{c}{ Group } \\
\cline { 2 - 4 } & Control & LDA & RDA \\
\hline Number of cows & 5 & 3 & 4 \\
Mean age \pm SE (years) & $5.86 \pm 1.59$ & $4.3 \pm 1.8$ & $5.50 \pm 2.7$ \\
Mean post parturient time \pm SE (day) & $16.5 \pm 5.22$ & $21.3 \pm 4.65$ & $25.5 \pm 7.22$ \\
\hline
\end{tabular}

Table 2: Clinical picture of control cows and those with LDA and RDA.

\begin{tabular}{lcccc}
\hline & \multicolumn{3}{c}{ Group } & \multirow{2}{*}{ P value } \\
\cline { 2 - 4 } & Control & LDA & RDA & 0.529 \\
Body temperature ${ }^{\circ} \mathbf{C}$ & $37.8 \pm 0.7$ & $36.8 \pm 0.5$ & $37.2 \pm 0.4$ & 0.001 \\
Respiratory rate $/$ min. & $37.5 \pm 0.6^{\mathrm{a}}$ & $39.7 \pm 0.8^{\mathrm{ab}}$ & $42.5 \pm 0.7^{\mathrm{b}}$ & 0.025 \\
Pulse rate / min. & $72.6 \pm 1.5^{\mathrm{a}}$ & $78.5 \pm 2.7^{\mathrm{ab}}$ & $81.0 \pm 1.9^{\mathrm{b}}$ & \\
Ruminal movement & $3 / 2 \mathrm{~min}$ & $2 / 2 \mathrm{~min}$ & $1 / 2 \mathrm{~min}$ & \\
\hline
\end{tabular}

Different superscripts of the same row indicate significant difference at $\mathrm{P}<0.05$.

Table (3): Urine analysis and abomasal fluid pH of control cows and those with LDA and RDA.

\begin{tabular}{lccc}
\hline \multirow{2}{*}{ Parameters } & Groups & Group & \\
\cline { 2 - 4 } pH & Control & LDA & $6 \pm 0.2^{\mathrm{b}}$ \\
Protein & $8.3 \pm 0.3^{\mathrm{a}}$ & $6.5 \pm 0.2^{\mathrm{b}}$ & $-\mathrm{ve}$ \\
Glucose & $-\mathrm{ve}$ & $-\mathrm{ve}$ & $-\mathrm{ve}$ \\
Ketone bodies & $-\mathrm{ve}$ & $-\mathrm{ve}$ & $+++\mathrm{ve}$ \\
Blood & $-\mathrm{ve}$ & $+++\mathrm{ve}$ & $-\mathrm{ve}$ \\
Hemoglobin & $-\mathrm{ve}$ & $-\mathrm{ve}$ & $-\mathrm{ve}$ \\
Bilirubin & $-\mathrm{ve}$ & $-\mathrm{ve}$ & $-\mathrm{ve}$ \\
Abomasal fluid pH & $-\mathrm{ve}$ & $4.0 \pm 0.2^{\mathrm{b}}$ & $4.8 \pm 0.2^{\mathrm{b}}$ \\
\hline
\end{tabular}

Different superscripts of the same row indicate significant difference at $\mathrm{P}<0.05$.

Table (4): Hematological and serum biochemical changes control cows and those with LDA and RDA.

\begin{tabular}{|c|c|c|c|c|c|c|c|}
\hline \multirow[b]{2}{*}{ Variables } & \multicolumn{2}{|c|}{$\begin{array}{c}\text { Control } \\
(n=5)\end{array}$} & \multicolumn{2}{|c|}{$\begin{array}{l}\text { LDA } \\
(n=3)\end{array}$} & \multicolumn{2}{|c|}{$\begin{array}{l}\text { RDA } \\
(n=4)\end{array}$} & \multirow[t]{2}{*}{$P$ value } \\
\hline & Mean & SE & Mean & SE & Mean & SE & \\
\hline RBCs $\left(\times 10^{12} / \mathrm{L}\right)$ & 7.2 & 0.5 & 7.5 & 3.60 & 7.8 & 3.41 & 0.984 \\
\hline Hemoglobin (gm/dl) & 90.76 & $2.28^{\mathrm{a}}$ & 100.4 & 4. $16^{\mathrm{ab}}$ & 107 & 4. $60^{\mathrm{b}}$ & 0.029 \\
\hline $\operatorname{PCV}(\mathrm{L} / \mathrm{L})$ & 0.346 & $0.01^{\mathrm{a}}$ & 0.38 & $0.01^{\mathrm{b}}$ & 0.43 & $0.01^{\mathrm{c}}$ & 0.001 \\
\hline WBCs $\left(\times 10^{12} / \mathrm{L}\right)$ & 10.8 & $0.5^{\mathrm{a}}$ & 10.2 & $0.6^{\mathrm{a}}$ & 15.5 & $0.5^{\mathrm{b}}$ & $<0.001$ \\
\hline Neutrophils $\left(\times 10^{9} / \mathrm{L}\right)$ & 3.2 & $0.6^{\mathrm{a}}$ & 3.8 & $0.4^{\mathrm{a}}$ & 8.5 & $0.5^{b}$ & $<0.001$ \\
\hline Lymphocytes (x10 $/ \mathrm{L})$ & 4.8 & $0.3^{\mathrm{a}}$ & 4.3 & $0.6^{\mathrm{a}}$ & 5.9 & $0.6^{\mathrm{a}}$ & 0.124 \\
\hline Monocytes $\left(\times 10^{9} / \mathrm{L}\right)$ & 0.5 & $0.1^{\mathrm{a}}$ & 0.5 & $0.2^{\mathrm{a}}$ & 0.4 & $0.1^{\mathrm{a}}$ & 0.811 \\
\hline Sodium (mmol/L) & 142.5 & $1.4^{\mathrm{a}}$ & 132.0 & $1.75^{\mathrm{b}}$ & 131.3 & $1.91^{\mathrm{b}}$ & 0.001 \\
\hline Potassium (mmol/L) & 4.6 & $0.2^{\mathrm{a}}$ & 3.5 & $0.17^{\mathrm{b}}$ & 3.2 & $0.091^{\mathrm{b}}$ & $<0.001$ \\
\hline Chloride (mmol/L) & 99.2 & $3.0^{\mathrm{a}}$ & 78.0 & $1.1^{\mathrm{b}}$ & 75.0 & $1.5^{\mathrm{b}}$ & $<0.001$ \\
\hline Calcium (mmol/L) & 4.9 & $0.05^{\mathrm{a}}$ & 1.83 & $0.1^{b}$ & 1.7 & $0.05^{\mathrm{b}}$ & $<0.001$ \\
\hline Glucose (mmol/L) & 2.2 & $0.38^{\mathrm{a}}$ & 3.82 & $0.34^{\mathrm{b}}$ & 4.85 & $0.31^{\mathrm{b}}$ & 0.001 \\
\hline Total proteins (g/L) & 72 & $2^{a}$ & 75 & $4.1^{\mathrm{a}}$ & 88 & $3^{b}$ & 0.006 \\
\hline ALT (IU/L) & 20.1 & $0.91^{\mathrm{a}}$ & 31.04 & $0.62^{b}$ & 33.3 & $0.83^{b}$ & $<0.001$ \\
\hline AST ( IU/L) & 45.2 & $0.64^{\mathrm{a}}$ & 73.02 & $6.41^{b}$ & 78.00 & $0.58^{\mathrm{b}}$ & $<0.001$ \\
\hline LDH (IU/L) & 44.3 & $7.81^{\mathrm{a}}$ & 495.2 & $8.21^{\mathrm{b}}$ & 480.7 & $9.52^{\mathrm{b}}$ & $<0.001$ \\
\hline CPK (IU/L) & 64.31 & $0.81^{\mathrm{a}}$ & 95.20 & $3.81^{\mathrm{b}}$ & 88.5 & $4.71^{\mathrm{c}}$ & $<0.001$ \\
\hline Urea (mmol/L) & 33.93 & $3.48^{\mathrm{a}}$ & 86.3 & $6.99^{\mathrm{b}}$ & 91.79 & $7.93^{\mathrm{b}}$ & $<0.001$ \\
\hline Creatinine (mmol/L) & 130.8 & $2.74^{\mathrm{a}}$ & 181.22 & $6.27^{\mathrm{b}}$ & 185.64 & $4.42^{\mathrm{b}}$ & $<0.001$ \\
\hline
\end{tabular}

Different superscripts of the same row indicate significant difference 
Urinalysis. Urinalysis demonstrated a significant reduction in $\mathrm{pH}$ value $(<0.001)$ in cows with LDA and LDA compared to control. Ketone bodies were also increased in urine of cows with LDA and LDA compared to control (Table 3).

Abomasal fluid pH. Measuring abomasal fluid $\mathrm{pH}$ showed a significant increase $(\mathrm{P}<0.001)$ in $\mathrm{pH}$ value in cases of LDA and RDA compared to control (Table 3).

Hematological changes. A significant incr-ease of $\mathrm{Hb}$ concentration, $\mathrm{PCV} \%$, leucocytic count and neutrophil count was detected in cows with RDA compared to control. However, cows with LDA showed a significant increase in the PCV\% only compared to control. In addition, a significant increase in the PCV\% and WBCs count was detected in cows with RDA compared to LDA. On the other hand, no significant change of RBCs, lymphocyte and monocyte was detected among the three groups (Table 4).

Serum biochemical changes. There was a significant decrease $(\mathrm{P}<0.001)$ of serum sodium, potassium, chloride, calcium in cows with LDA and RDA compared to control and a significant increase $(\mathrm{P}<0.05)$ in glucose and serum total proteins in cows with RDA compared to control. On the other hand, there was a significant increase $(\mathrm{P}<0.001)$ in lactate dehydrogenase, creatine phosphokinase, alanine aminotransferase aspartate aminotransferase (AST), urea and creatinine in cows with LDA and RDA compared to control. Additionally, both serum total proteins and CPK were significantly increased in cows with RDA compred to cows with LDA (Table 4).

\section{Discussion}

Abomasal displacement is among the most commonly encountered disease in dairy veterinary practice (Delgado-Lecaroz et al., 2000). Cases with abomasal displacement were recorded within the period from 21 to 25 days after parturition, which was similar to those recorded by (Constable et al., 1991; Zadnik, 2003b). The occurrence of AD during this period may be related to the feeding behavior. In addition to a change in amount of feed, the composition of ration is also changed for postpartum dairy cows. In the dry period the diet consists mainly of roughage, while after calving the ration is rich in concentrates (Van Winden et al., 2003). A diet containing concentrates compared with a ration of only roughage resulted in a reduced myoelectrical activity of the abomasum in sheep (Lester and Bolton, 1994).

Diseased cows were afebrile with increased pulse and respiratory rates. These findings conform to those of Goetze and Müller (1990). On the other hand, the ruminal movements were reduced in cows with LDA and RDA. Several explanations were proposed to elucidate the relationship between rumen movement and the $\mathrm{AD}$. It is known that the only pathway of diminishing rumen volume is via a drain towards the abomasum, which leads to a distension of the abomasal wall (Martens, 2000). When the abomasal wall is stretched too much, as in displacement, this can lead to reduction of motility via the vagus nerve (Geishauser et al., 1998b). Moreover, general, rumen activity declines during a moderate hypocalcemia (Jorgensen et al., 1998) that usually occurs with $\mathrm{AD}$ and consider a risk factor for its occurrence.

Clinical examination of diseased cows indicated dullness, poor appetite, sudden drop of milk yield, ketotic breath, scant pasty faeces, reduction of rumination and distention of the left or right side of the abdomen according to the type of displacement. Moreover, high pitched resonant pings were audible on simultaneous percussion and auscultation of the dorsal flank, especially in the cranial third of the paralumbar fossa in cases with LDA and on the right dorsolateral aspect of the body in cases with RDA. On rectal palpation, the rumen was displaced medial than normal in left abomasal displacement, while in right displacement, the distended abomasum was palpated rectally. All these clinical findings were nearly similar to those recorded by Buchanan et al., (1991) and Jubb et al., (1991). The cows with displacement defecate less frequently and the feces usually scanty (Radostits et al., 2007) because emptying of the content from the organ is obstructed (Zadnik et al., 2003a).

Urine examination indicated ketonuria and aciduria. Similar result was demonstrated by Latimer and Mahaffey, (2003). This paradoxical aciduria could be attributed to excretion of hydrogen ions and retention of sodium in the face of hypokalemia (Anderson, 1980). The ketonuria occurred in abomasal displacement could be primary and caused by the hypoglycemia that occurs peripartum and considered as a risk factor for abomasal displacement (Rohrbach et al., 1999) or may be secondary to abomasal displacement (Itoh et al., 1998). 
Measuring abomasal fluid $\mathrm{pH}$ demonstrated a significant increase in $\mathrm{pH}$ value in cases of LDA and RDA compared to control. Several theories are proposed to explain the elevation of abomasal fluid $\mathrm{pH}$. First, when fluid of the rumen is transported to the abomasum and not mixed with the acid of the abomasal contents due to decreased motility of the abomasum, the $\mathrm{pH}$ will rise. (Svendsen, 1969). The elevation in $\mathrm{pH}$ may allow the microbes in the fluid to produce methane and carbon dioxide, which are the main components of gas in a displaced abomasum (Mackie et al., 1992). Finally, the cause of the elevation in $\mathrm{pH}$ in the abomasal fluid could be due to malabsorption of bicarbonate in the omasum. In a healthy ruminant, the omasum absorbs bicarbonate and other buffers such as phosphates. When the omasum does not function properly, the buffering capacity of the contents entering the abomasum will be higher, resulting in higher $\mathrm{pH}$ values in the abomasal fluid (Engelhardt and Hauffe, 1975). The rise in $\mathrm{pH}$ of abomasal contents can play an important role in the etiology of abomasal displacement in dairy cows due to continued fermentation with a poor motility of abomasum (Van Winden et al., 2002).

Blood picture in cows with abomasal displacement indicated a significant increase of $\mathrm{PCV} \%$ and $\mathrm{Hb}$ concentration, which could be attributed to hemoconcentration and dehydration (Jubb et al., 1991 and Rohn et al., 2004). The hemoconcentration and dehydration are associated with insufficient abomasal emptying due to duodenal-abomasal reflux in addition to decreased food and water intake (Ward et al., 1994; Geishauser and Seeh, 1996). Not only does hemoconcentration produce elevation in hematocrite value but also rises the total serum proteins as demonstrated by our result. The leucocytosis and neutrophilia observed in RDA might be an immunological response to the endotoxemia and abomasitis that occurs secondary to RDA (Zadnik, 2003b).

Serum biochemical changes in cows with AD revealed a significant decrease of serum sodium, potassium, chloride, calcium with significant increase in glucose, serum total proteins, urea, creatinine, lactic dehydrogenase, creatine phosphokinase, alanine aminotransferase and aspartate aminotransferase (AST). These results were agreeable with those of O'Zkank and Poulsen, (1986) and Zadnik, (2003b). Metabolic alkalosis with hypochloremia and hypokalemia associated with abomasal displacement could be attributed to abomasal atony, continued secretion of hydrochloric acid into the abomasum and impairment of flow into the duodenum (Svendsen, 1969). In addition, without stimulation by the passage of ingesta, the duodenum does not secrete pancreatic $\mathrm{HCO}_{3}$, creating a relative increase in $\mathrm{HCO}^{-}$- and producing metabolic alkalosis (Cunningham, 2002). The significant reduction of sodium electrolyte in cases of LDA and RDA could result from the metabolic acid-base imbalance due to duedeno-abomasal reflux and endotoxemia (Geishauser and Seeh, 1996; Ohtsuka, 1997). Our results demonstrated a significant reduction in calcium in cows with LDA and RDA. Similar results were reported by Delgado-lecaroz et al., (2000) and Zadnik, (2003b). The puerperal hypocalcemia represents a significant risk factor for development of $\mathrm{AD}$ in cows (Houe et al., 2001).

The significant increase of serum ALT and AST suggested a disturbance in liver function (Voros and Karsai, 1987; Lenz, 1993) that could be attributed to hepatic lipidosis, endotoxemia and hepatocyte damage (Zadnik, 2003b). The significant increases of the activities of lactate dehydrogenase (LDH) and creatinine phosphokinase (CPK) enzymes might be attributed to affection of liver (LDH) and affection of heart and skeletal muscles (CPK) associated with the muscular exertion and excitement occurring during displacement. The significant increase in serum urea and creatinine is usually attributed to dehydration and decreased renal blood flow (renal ischemia) (Anderson, 1980).

Our result demonstrated a significant increase in the blood glucose level in cows with displaced abomasum, a result that conforms to that of Zadnik (2003b). It has been found that cows with $\mathrm{AD}$ have often an elevated glucose and insulin level in the blood circulation (Muylle et al., 1990; Cupere et al., 1991; Itoh et al., 1998).

Holtenius et al., $(1998,2000)$ reported decreased abomasal motility in cows with high insulin combined with high glucose levels. The latter situation reflects the general metabolic characteristic of a cow in postpartum negative energy balance. On the other hand, Van Winden et al., (2003) found low levels of insulin and glucose in cows that developed DA 10 days later. The elevated glucose and insulin levels found in DA cows are probably secondary to the disorder, whereas low glucose and insulin levels precede DA (Van Winden and Kuiper, 2003). 
The exact mechanism by which the abomasal displacement, specially the right-sided type leads to hyperglycemia is unknown. However, Zadnik (2003b) reported that hyperglycemia may be associated with impaired outflow of pancreatic juice and disturbed blood circulation in the pancreatic parenchyma because of changes in the duodenal and omental position that occur during dislocation of abomasum. Whether or not AD produces changes in glucose concentration, Geishauser et al., (1998b) favoring the opinion that glucose concentration does not have diagnostic significance for dislocation of abomasum.

\section{Conclusion}

On the basis of our results and literature, it is concluded that abomasal displacement is more expected from the $21^{\text {st }}$ day after parturition and usually associated with hemoconcentration, electrolyte imbalance and disturbances in liver and hepatic function. Subclinical hypocalcemia and hyperglycemia are also associated with abomasal displacement. Therefore it is recommended to pay special attention to dairy cows starting from the $3^{\text {rd }}$ week postpartum by maintaining of the energy balance, electrolyte balance and calcium homeostasis.

\section{Acknowledgement}

The authors gratefully acknowledge the Department of Animal Medicine, Faculty of Veterinary Medicine, Benha University (Egypt) for supporting this research.

\section{References}

Anderson, N. V. (1980): Veterinary Gastroentero-logy Printed in USA, Philadelphia.

Bartlett, P. C.; Kopcha, M.; Coe, P. H.; Ames, N. K.; Ruegg, P. L. and Erskine, R. J. (1995): Economic comparison of pyloro-omentopexy vs. rolland- toggle procedure for the treatment of left displacement of the abomasum in dairy cattle. J. Am. Vet. Med. Assoc. 206: 1156-1162.Braun, U.; Wild, K.; Guscetti, F. (1997): Ultrason- ographic examination of the abomasum of 50 cows. Vet. Rec. 140 (4): 93-98.

Breukink, H. J. and Kroneman., J. (1963): Een nieuw diagnostisch hulpmiddel bij het onderzoek van het rund op de aanwezigheid van een gedilateerde en/of gedisloceerde lebmaag; het zgn. "Steelband-effect". Tijdsch. Diergeneeskd. 88: 282-291.

Breukink, H. J. and de Ruyter, T. (1976): Abomasal displacement in cattle: influence of concentrates in the ration on fatty acid concentrations in ruminal, abomasal, and duodenal contents. Am. J. Vet. Res. 37(10):1181-1184.

Buchanan, M.; Cousin, D. A.; MacDonald, N. M. and Armour, D. (1991): Medical treatment of right-sided dilatation of the abomasum in cows. Vet. Rec. 129 (6):111112.

Constable, P.D.; Jean, G. S.; Hull, B. L.; Rings, M. R. and Hosffsis, G. F. (1991): Prognostic value of surgical post-operative findings in cattle. Am.Vet. Med. Assoc. 198:2077-2085.

Constable, P. D.; Jean, G. S.; Koenig, G. R.; Hull, B. L. and Rings, M. R., (1992b): Abomasal luminal pressure in cattle with abomasal volvulus or left displaced abomasum. J. Am. Vet. Med. Assoc. 201:1564-1568.

Constable, P. D.; Miller, G. Y. and Hoffsis, G. F. (1992a): Risk factors for abomasal volvulus and left abomasal displacement in cattle. Am. J. Vet. Res. 53: 11841192.

Cunningham, J. G. (2002): Textbook of Veterinary Physiology, $3^{\text {rd }}$ ed. W. B. Saunders Company, Philadelphia, USA. pp. 255-279.

Cupere, F.; Muylle, E.; Van der Hende, C. and Oyeart W. (1991): Metabolic profile tests in high yielding normal cows and in cows suffering from abomasal displacement. Bovine Practice 26: 129-130.

Delgado-Lecaroz, R.; Warnick, L. D.; Guard, C. L.; Smith, M. C. and Barry, D. A. (2000): Cross-sectional study of the association of abomasal displacement or volvulus with serum electrolyte and mineral concentrations in dairy cows. Vanadian Vet. J. 41(4), 301-305.

Dirksen, G. (1962): Die Eweiterung velgerung and Drehung des labmagens beim Rind. Hannover, Tierarztl" Hochsch., Habilchr., Verlag Parey, Berlin und Hamburg.

Doumas, B. T.; Bayse, D. D.; Carter, R. J.; Peters Jr, T. and Schaffer, R. (1981): A candidate reference method for determination of total protein in serum. I. Development and validation. Clinical Chemistry 27, 1642-1650.

Engelhardt, W. V. and Hauffe, R. (1975): Role of the omasum in absorption and secretion of water and electrolytes in sheep and goats. In: McDonalds, I., and E. Warner (eds) Digestion and metabolism in the ruminant: Proc. IV Int. Symp. Ruminant physiology, Sydney, Australia, August 1974, pp. 216-230. University of New England Publishing Unit, Armidale.

Faweet, J. K. and Scott, J. E. (1960): Determination of urea. J. Clin. Pathol. 13:156.

Feldkemp, C. S. (1974): Colorimetric determination of chloride ions. Z. Kilm. Chem. Klin. Biochem., 10: 280.

Geishauser, T. and Seeh, C. (1996): Duodeno-abomasal reflux in cows with abomasal displacement, J. Vet. Med. A 43, 445-50.

Geishauser, T.; Leslie, K. and Duffield, T. (2000) : Metabolic aspects in the etiology of displaced abomasum, Vet. Clinics North America: Food Animal Practice. 16, 255-265.

Geishauser, T.; Leslie, K.; Duffield, T.; Sandals, D. and Edge, V. (1998b): The association between selected metabolic parameters and left abomasal displacement in dairy cows. J. Vet. Med. A 45:499-511.

Geishauser, T.; Reiche D. and Schemann M. (1998b): In vitro motility disorders associated with displaced abomasum in dairy cows. Neurogastroenterol. and Motility. 10: 395-401.

Gelfert, C. C.; Hauser, S.; Loptien, A.; Montag, N.; Passmann, M.; Baumgartner, W. and Staufenbiel, R. (2006): Impact of a simultaneous application of anionic salts and rumen buffer on acid-base balance and mineral metabolism in dairy cows. Berl Munch Tierarztl Wochenschr. 119 (5-6): 244-50.

Glinder, E. M. and King, J. D. (1972): Rapid colorimetric determination of calcium in biological fluid with methyl thymol blue. Am J. Clin. Pathol. 58: 376-382.

Goetze L. and Müller, M. (1990): The therapy of hypovolemic shock in cows with right-sided abomasal displacement. Zentralbl Veterinarmed A. 37(4):300-309. 
Henry, R. F.; Cannon, D. C. and Winkelman, J. W. (1974): Clinical chemistry principals and techniques, $2^{\text {nd }}$ Ed. Harper, and Roe, Hagerstown, M.D.

Holtenius, K.; Jacobsson, S. O. and Holtenius P. (1998): Effects of intravenous infusion of glucose and pancreatic glucagon on abomasal function in dairy cows, Acta Veterinaria Scandinavica 39: 291-300.

Holtenius, K.; Sternbauer, K.and Holtenius P. (2000): The effect of the plasma glucose level on the abomasal function in dairy cows. J. Animal Sci., 78: 1930-1935.

Houe, H.; Østergaard, S.; Thilsing-Hansen, T.; Jørgensen, R. J.; Larsen, T.; Sørensen, T.; Agger, J.F. and Blom, J.Y., (2001): Milk fever and subclinical hypocalcaemia, Acta Veterinaria Scandinavica, 42:1-29.

Itoh, N.; Koiwa, M.; Hatsugaya, A.; Yokota, H.; Taniyama, H.; Okada, H. and Kudo, K. (1998): Comparative analysis of blood chemical values in primary ketosis and abomasal displacement in cows. Zentralbl Veterinarmed A. 45(5):293-298.

Jorgensen, R .J.; Nyengaard, N. R.; Hara, S.; Enemark J. M. and Andersen, P. H. (1998): Rumen motility during induced hyper- and hypocalcaemia, Acta Vet. Scand. 39:331-338.

Jubb, T. F.; Malmo, J.; Davies, G. M. and Vawser, A.S. (1991): Left-side displacement of the abomasum in dairy cows at pasture. Aust. Vet. J. 68, 140-142.

Kelly, W. R. (1984): Veterinary clinical diagnosis. $3^{\text {rd }}$ ed., Printed in Great Britain by William Clows Beccles, London.

Latimer, K. S.; Mahaffey, E. A. and Prasse, K. W., (2003): Veterinary laboratory medicine: Clinical pathology, $4^{\text {th }}$ ed. Iowa State Press, Ames, pp. 136-161.

Lenz, U. (1993): Untersuchungen zum Gerinnungs-status und zur Bedetung der Gerinnungsinhibitoren Antithrombin III uns protein C in der Diagnostik der Hepatosteatose von Kuhen mit linksseitiger Labmagenverlagerung. Hannover, Tieraztol. Hoch-sch., Diss.

Lester, G. D. and Bolton, J. R. (1994):. Effect of dietary composition on abomasal and duodenal myoelectrical activity, Res. Vet. Sci., 57:270-276.

Lott, J. A. (1975): Determination of glucose. Clin.Chem. 21:1745.

Mackie, R. I.; White, B. A. and Bryant, M. P. (1992): Methanogenesis, biochemistry. In: Lederberg, J. (ed.) Encyclopedia of Microbiology,. Academic Press, San Diego. 3:97-109.

Martens, H. (2000): Relations between feeding, physiology of the forestomachs and pathogenesis of abomasal displacement, in: Fürll M. (ed.), Ätiologie, Pathogenese, Diagnostik, Prognose, Therapie und Prophylaxe der Dislocatio abomasi, Proceedings Internationaler Workshop, Leipzig, 14 Oktober 1998, Leipziger Universitätsverlag, Leipzig, pp. 81-101.

Martin, W. (1972): Left abomasal displacement: an epidemiological study. Canad. Vet. J. 13: 61-68.

Muylle, E. C.; Van den Hende, B.; Sustronck, B. and Deprez P. (1990): Biochemical profiles in cows with abomasal displacement estimated by blood and liver parameters, Zentralbl Veterinarmed A. 37(4): 259-263.

O'Zkan, K. and Poulsen, J. S. D. (1986): Changes in ionized calcium content and related clinical chemical parameters in cases of left sided abomasal displacement. Nordisk Veterinaer Medicin 38:277-287.

Ohtsuka, H., Ohki, K., Motoshi, T. (1997): Evaluation of blood acid-base balance after experimental administration of endotoxin in adult cow, Jpn. Vet. Med. Sci., 59:483-485.
Pehrson, B. G. and Shaver, R. D. (1992): Displaced abomasum: clinical data and effects of peripartal feeding and management on incidence. Proc. XVIIth World Buiatric Congress. (St. Paul) 1:116-120.

Radostits, O. M.; Gay, C. C.; Blood, D. C. and Hinchcliff, K.W. (2000): Diseases of the abomasum. In: Radostits, O.M., Gay, C.C., Blood, D.C. Hinchcliff, K.W. Veterinary Medicine: A textbook of the disease of cattle, sheep, pigs, goats and horses. 9th Ed.W.B. Saunders, London, Great Britain. pp. 322

Radostits, O. M.; Gay, C. C.; Hinchcliff, K.W. and Constable, P. D. (2007): Diseases of the abomasum. In: Radostits, O.M., Gay, C.C., Hinchcliff, K.W., Constable, P.D.Veterinary Medicine: A textbook of the diseases of cattle, horses, sheep, pigs and goats. $10^{\text {th }}$ ed. Elsevier Health Sciences, Philadelphia, PA, USA, pp. 353-374

Rec. G.S.C.C. (DGKC), (1977):. J. Clin. Chem. Clin. Biochem. 15:255.

Reitman, S. and Frankel, S. (1957): Determination of transaminases. Am. J. Clin. Pathol. 28:56.

Rohn, M.; Tenhagen, B. A. and Hofmann, W. (2004): Survival of dairy cows after surgery to correct abomasal displacement: 2. Association of clinical and laboratory parameters with survival in cows with left abomasal displacement. J.Vet. Med. A. 51(6):300-305.

Rohrbach, B. W.; Cannedy, A. L.; Freeman, K. and Slenning, B.D. (1999): Risk factors for abomasal displacement in dairy cows. J. Am. Vet. Med. Assoc. 214(11):1660-1663.

Sack, W.O. (1986): Abdominal topography of a cow with left abomasal displacement. Am. J. Vet. Res. 29(8):15671576.

Sastry, G. A. (1985): Veterinary clinical pathology. $3^{\text {rd }}$ ed. CBS Publishers distributors Delhi, India.

Schuch, M. (1993): A contribution of the displacement of the abomasum in Austrain dairy cows. $2^{\text {nd }}$ Sci. Cong. Egyp. Soc. Assuit, Egypt.

Svendsen, P. (1969): Etiology and pathogenesis of abomasal displacement of cattle. Nordisk Veterinaer Medicin 21, Supple, 1, 1-60.

Tietz, N. W. (1986): Fundamentals of clinical chemistry. W.B. Saunder Co., Philadelphia.

Van Winden S. C. L.; Muller K. E.; Kuiper R. and Noordhuizen J. P. T. M. (2002): Studies on the $\mathrm{pH}$ values of abomasal contents in dairy cows during the first 3 weeks after calving. J.Vet. Med. A. 49:157-160.

Van Winden, S. C. L.; Jorritsma, R.; Müller K. E. and Noordhuizen, J. P. T. M. (2003): Feed Intake, milk yield, and metabolic parameters prior to left displaced abomasum in dairy cows. J. Dairy Sci., 86: 1465-1471

Van Winden, S. C. L.; Kuiper, R. (2003b): Left displacement of the abomasum in dairy cattle: recent developments in epidemiological and etiological aspects. Vet. Res. 34:47-56.

Voros, K. L. and Karsai, F. (1987): Blut-und pasensaftveraderungen cordem Auftreten der linksseitigen Lambagenverlagerung bei Milchkuhen. Tierarzti. Umsch. 42:617-624.

Ward, J. L.; Smith, D. F.; Fubini, S. L. and DeuelArmando, D. N. (1994): Evaluation of abomasal outflow diversion as an experimental model of hypochloremic, hypokalemic metabolic alkalosis in lactating cows. Canad. J. Vet. Res., 58:13-19.

Young, D. S. (1990): Effect of drugs on clinical laboratory tests. $3^{\text {rd }}$ ed. AACC Press, Washington, D.C. 3:122-131.

Zadnik, T. (2003a): Review of anterior displacement of the abomasum in cattle in Slovenia. Vet. Rec. 5:24-25. 
Zadnik, T. (2003b): A comparative study of the hematobiochemical parameters between clinically healthy cows and cows with displacement of the abomasum. Acta Veterinaria (Beograd), 53 (5-6): 297-309.

\section{تغيرات إكلينيكيه وتغيرات في الصوره الكيمياء البيوحيويه وصوره الدم في الأبقار التي تعاني من إزاحه للامعده في مصر}

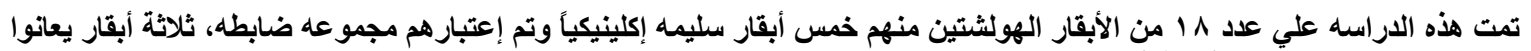

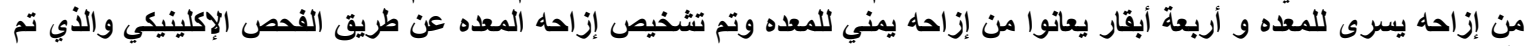

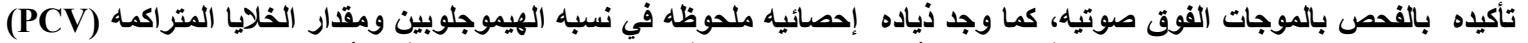

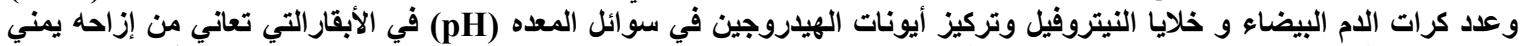

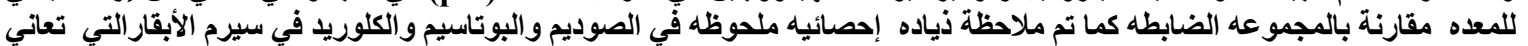

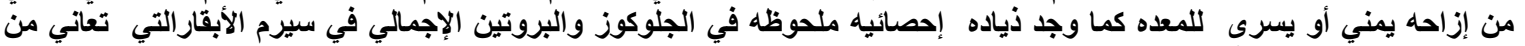

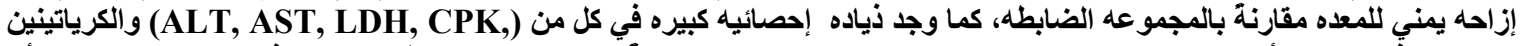

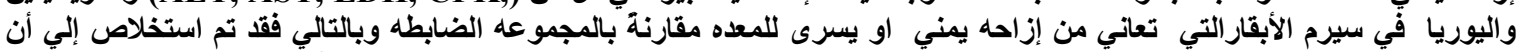

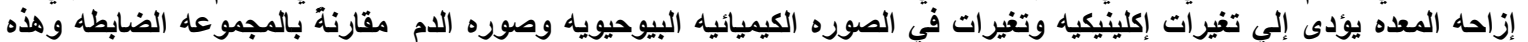
التغيرات تختلف علي حسب نوع الزئ الإزاحه. 